University of New Hampshire

University of New Hampshire Scholars' Repository

$9-1993$

\title{
Town-Village Contrasts in Alaskan Youth Aspirations
}

Lawrence C. Hamilton

University of New Hampshire, lawrence.hamilton@unh.edu

Carole L. Seyfrit

Old Dominion University

Follow this and additional works at: https://scholars.unh.edu/soc_facpub

Part of the Sociology Commons

\section{Recommended Citation}

Hamilton, L.C. and C.L. Seyfrit. (1993) "Town-village contrasts in Alaskan youth aspirations." Arctic 46(3):255-263.

This Article is brought to you for free and open access by the Sociology at University of New Hampshire Scholars' Repository. It has been accepted for inclusion in Sociology Scholarship by an authorized administrator of University of New Hampshire Scholars' Repository. For more information, please contact Scholarly.Communication@unh.edu. 


\title{
Town-Village Contrasts in Alaskan Youth Aspirations ${ }^{1}$ \\ LAWRENCE C. HAMILTON ${ }^{2}$ and CAROLE L. SEYFRIT ${ }^{3}$
}

(Received 11 January 1993; accepted in revised form 12 April 1993)

\begin{abstract}
Recent surveys of high school students in Alaska's Northwest Arctic and Bristol Bay regions reflect the social changes taking place in rural Native communities. Significant differences exist between the aspirations of young people in small villages and those in the larger towns that constitute regional hubs (Kotzebue and Dillingham). Town students, who attend more complete and varied high schools, express greater confidence in their educations and more interest in attending college. Jobs at Red Dog Mine, recently opened in the Northwest Arctic, appeal particularly to young males with strong ties to village life. This labor pool presents special challenges for the mine's goal of $100 \%$ Native employment, however. A majority of town students and about half of the village students expect to migrate permanently away from their home region. The likelihood of expecting migration increases curvilinearly with community size. Young women and collegeaspiring students disproportionately expect outmigration. Differential migration affects the acculturation and life prospects of individuals and shapes the demographic profile of Alaskan villages, towns, and cities.
\end{abstract}

Key words: Alaska, Eskimo, Inuit, Yupik, youth, mining, education, employment, migration, social change

RÉSUMÉ. De récentes études effectuées sur la population des élèves du secondaire deuxième cycle dans les régions du nord-ouest de l'Arctique alaskien et de la baie de Bristol reflètent les changements sociaux qui ont lieu dans les communautés rurales autochtones. Il existe des différences significatives entre les aspirations des jeunes vivant dans les petits villages et ceux des grandes villes qui constituent des centres régionaux, comme Kotzebue et Dillingham. Les élèves des villes, qui fréquentent des écoles secondaires plus grandes et plus diverses, manifestent plus de confiance dans leur éducation et plus d'intérêt à poursuivre au niveau collégial. Les emplois à Red Dog Mine, qui vient d'ouvrir dans le nord-ouest de l'Arctique, attirent particulierement les jeunes de sexe masculin qui ont des liens importants avec la vie de village. Cette main-d'oeuvre représente cependant des défis particuliers pour la mine dont la politique vise à employer $100 \mathrm{p}$. cent d'autochtones. Une majorité d'élèves citadins et environ la moitié des élèves vivant dans des villages espèrent quitter leur région natale de façon permanente. La probabilité du désir d'émigrer augmente de façon curviligne avec la taille de la communauté. Les jeunes femmes et les élèves qui désirent aller au collège comptent sur une migration externe de façon disproportionnée. Une migration différentielle affecte l'acculturation et les ouvertures tout au long de la vie des individus, et façonne le profil démographique des villages, municipalités et villes alaskiennes.

Mots clés : Alaska, Esquimau, Inuit, yupik, jeunes, exploitation minière, éducation, emploi, migration, changement social

Traduit pour le journal par Nésida Loyer.

\section{INTRODUCTION}

Among the most striking traits of Alaskan villages today is the rapid pace of social change. Chance (1990:187) describes the strangeness of coming to Barrow in 1985 and finding it radically altered since his anthropological field work 15 years before: "In contrast to earlier trips, it seemed like I was entering a new world." Extractive industrialization, such as the oil boom that transformed Barrow, drives social change in many once-remote Native communities. Mining and oil development finance other agents of social change, including public-sector jobs, the shift from subsistence to cash economies, transfer payments, rural secondary education, and of course television. In 1982 one author, alarmed about its capacity to change Inuit culture, called television "a late and powerful stage of ethnocide" (Graburn, 1982:16). Today satellite dishes loom over village skylines, and television floods images of Californian life into homes hundreds of kilometres from pavement.

Recent books provide rich accounts of modern Inuit and Yup'ik culture (Chance, 1990; Condon, 1987; Duffy, 1988; Fienup-Riordan, 1990; Jorgensen, 1990; Kizzia, 1991; Oswalt, 1990). This article explores similar social terrain, though we look at different communities and depart from those earlier works in several respects. Unlike others except Condon, we focus particularly on adolescents, whose life choices and aspirations foreshadow the destiny of many arctic villages:
Before the impact of Eurocanadian culture ... . [a] young man would aspire to be a good hunter with a hardworking wife and healthy children. He would seek to be respected as a wise and knowledgeable member of the community. . . . Beyond this, however, no other opportunities were possible.

This scenario stands in marked contrast to the myriad choices now available to Inuit adolescents. . . . [they] are gradually becoming more like adolescents in the South for whom making future life plans assumes critical importance even before the completion of high school. [Condon 1987:171.]

During spring 1992, as part of ongoing research about rapid social change and rural youth, we surveyed hitgh school students and recent graduates in Alaska's Bristol Bay and Northwest Arctic regions. Our interest centered on how social changes resulting from resource-extraction development affect young people's plans and aspirations (Seyfrit and Hamilton, 1992b). We obtained responses from majorities of the high school students in 15 communities. These communities are all predominantly Native, but they range in size from small villages with few jobs to larger towns (Dillingham and Kotzebue) where the job opportunities of a whole region concentrate. Oswalt (1990:181) writes of another such town:

Although Bethel is an unsettled and sometimes unsettling place in which to live, it is the most prominent way-station to Americanization for those Kuskokwim Eskimos seeking to change in that direction.

\footnotetext{
'Research supported by a grant from the National Science Foundation (DPP-9111675)

${ }^{2}$ Department of Sociology, University of New Hampshire, Durham, New Hampshire 03824-3586, U.S.A.

${ }^{3}$ Department of Sociology and Criminal Justice, Old Dominion University, Norfolk, Virginia 23529-0090, U.S.A.

(CThe Arctic Institute of North America
} 
Regional hubs including Barrow, Dillingham, Kotzebue, and Nome fulfill similar way-station roles in their respective regions. Our data comparing town youth with their peers from surrounding villages thus provide a cross-sectional glimpse of the process of social change.

The Northwest Arctic recently became the site of the world's second-largest zinc mine (Red Dog Mine), which promises to substantially alter its economy. The Bristol Bay area, traditionally dependent on fishing, has not experienced industrial development and so forms a possible comparison area. Although our initial attention focused on social impacts of Red Dog Mine, we found the most striking contrasts not between Red Dog's Northwest Arctic and the Bristol Bay region, but between communities of different sizes within each region.

\section{BACKGROUND}

Our survey covered high school students in 15 rural Alaskan communities: 10 in the Northwest Arctic Borough and 5 in the Bristol Bay region (Table 1; Figs. 1 and 2). Kotzebue functions as transportation, commercial, and administrative hub for the Northwest Arctic. Similarly Dillingham is the Bristol Bay region's hub. Most of these 15 communities are incorporated as second-class cities, but subjectively the term "city" does not seem apt. In this article we refer to the two regional hubs, Kotzebue and Dillingham (populations 2000-3000), as "towns" and to the outlying bush communities (populations below 700) as "villages."

TABLE 1. Towns and villages studied: population, percentage Native, number of students enrolled in grades 9-12, and percentage of enrolled students completing survey ${ }^{\mathrm{a}}$

\begin{tabular}{lcccr}
\hline \hline \multicolumn{1}{c}{ Place } & $\begin{array}{c}1990 \\
\text { population }\end{array}$ & \% Native & $\begin{array}{c}\text { Students } \\
\text { in 9-12 }\end{array}$ & $\begin{array}{r}\text { Response } \\
\text { rate (\%) }\end{array}$ \\
\hline $\begin{array}{l}\text { Northwest Arctic } \\
\text { Town }\end{array}$ & & & & \\
Kotzebue & 2751 & 75.1 & 141 & 70.2 \\
Villages & & & & \\
Ambler & 311 & 89.7 & 19 & 89.5 \\
Buckland & 318 & 95.0 & 27 & 88.9 \\
Deering & 157 & 94.3 & 11 & 100.0 \\
Kiana & 385 & 93.5 & 34 & 82.4 \\
Kivalina & 317 & 97.5 & 32 & 68.7 \\
Noatak & 333 & 96.7 & 30 & 73.3 \\
Noorvik & 531 & 93.8 & 34 & 64.7 \\
Selawik & 596 & 95.5 & 40 & 65.0 \\
Shungnak & 223 & 94.6 & 13 & 84.6 \\
& & & & \\
Bristol Bay & & & & \\
Town & & & & \\
Dillingham & 2017 & 55.8 & 137 & 69.3 \\
Villages & & & & \\
Aleknagik & 185 & 83.2 & 4 & 100.0 \\
Manokotak & 385 & 95.6 & 21 & 81.0 \\
New Stuyahok & 391 & 95.9 & 19 & 52.6 \\
Togiak & 613 & 87.3 & 40 & 55.0 \\
\hline \hline
\end{tabular}

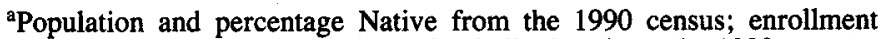
figures supplied by respective school districts in early 1992; survey conducted during spring 1992.
The Northwest Arctic Borough encompasses some $97000 \mathrm{~km}^{2}$, with a 1990 population just over 6000 people (our demographic statements reflect the 1990 Census). Eighty-five percent of these people are Native Americans, mainly Inupiat Eskimo. Nearly half reside in Kotzebue and most of the rest in ten coastal or upriver villages. Almost one-fifth of Northwest Arctic residents fall below the poverty line. Among Northwest Arctic Natives, per capita income in 1989 was about $\$ 7000$ (Kotzebue, $\$ 9000$; villages, $\$ 4500-9000$ ); among all Alaskans it was $\$ 17610$.

The Bristol Bay region in southwest Alaska has similar isolation and poverty, set in a milder subarctic climate. To date, Bristol Bay has not seen large-scale mining or oil development such as that occurring in arctic Alaska. Fishing remains the main commercial activity. The Dillingham Census Area, which includes Dillingham and the four Bristol Bay villages we studied, had a 1990 population of about 4000 people. Seventy-three percent of these people are Native, predominantly Yup'ik Eskimo. Half the area's population lives in Dillingham. Almost one-fourth of Dillingham Census Area residents fall below the national poverty level; Native per capita income in 1989 was $\$ 8600$ (Dillingham, $\$ 14500$; villages, $\$ 4000-8000$ ).

Costs of living in the bush far exceed those in the lower 48 U.S. states. The Alaska Federation of Natives (1989:34) reports that a Native family of four living in Bethel, Kotzebue, or Nome spends about $62 \%$ more per week on food, $165 \%$ more on electricity, and $46 \%$ more on a barrel of heating oil than does a family of four living in Anchorage - and

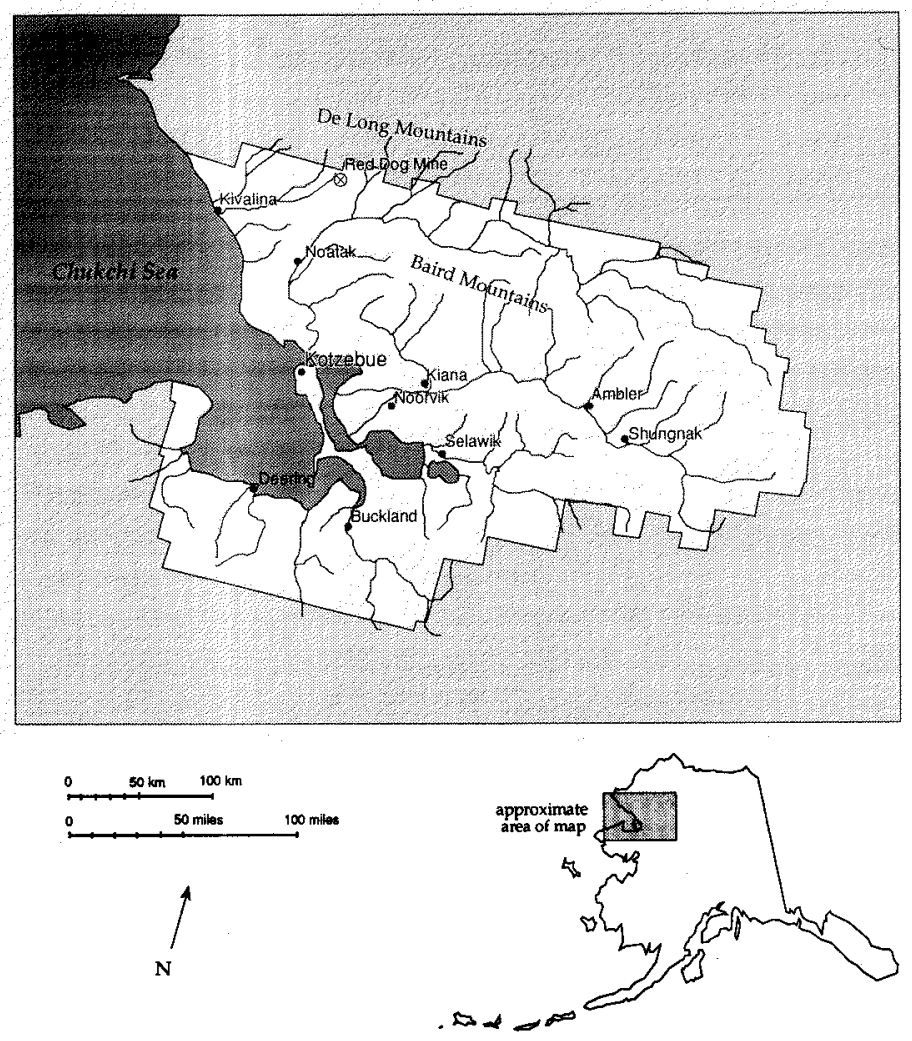

FIG. 1. Northwest Arctic region communities studied, with regional corporation boundaries. 
Anchorage itself is not cheap. In bush villages prices are higher still. Arctic communities face much colder weather than Anchorage, and bush transportation is always problematic. Many villages have no sewer systems and so face waste disposal and public health problems as well as daily inconvenience.

In Bristol Bay and the Northwest Arctic people survive with help from federal and state subsidies. This help includes not only direct payments to individuals but also housing, education, water supplies, public-sector jobs, medical and social services, and mail subsidies that keep bush airlines flying. Without subsidies, the villages could scarcely exist; at present, many are rapidly growing. As one villager told us, "Everything has been free for a whole generation here." Despite a low standard of living, subsidies allow much of what cash does enter the villages to be spent as discretionary income. Any substantial reduction in subsidies, as might happen with declining state oil revenues, will make village life more difficult and bring pressure for outmigration.

Subsistence hunting and fishing contribute to many families' food supply. Fall (1990), Jorgensen (1990), and Wolfe and Walker (1987) describe efforts to quantify this
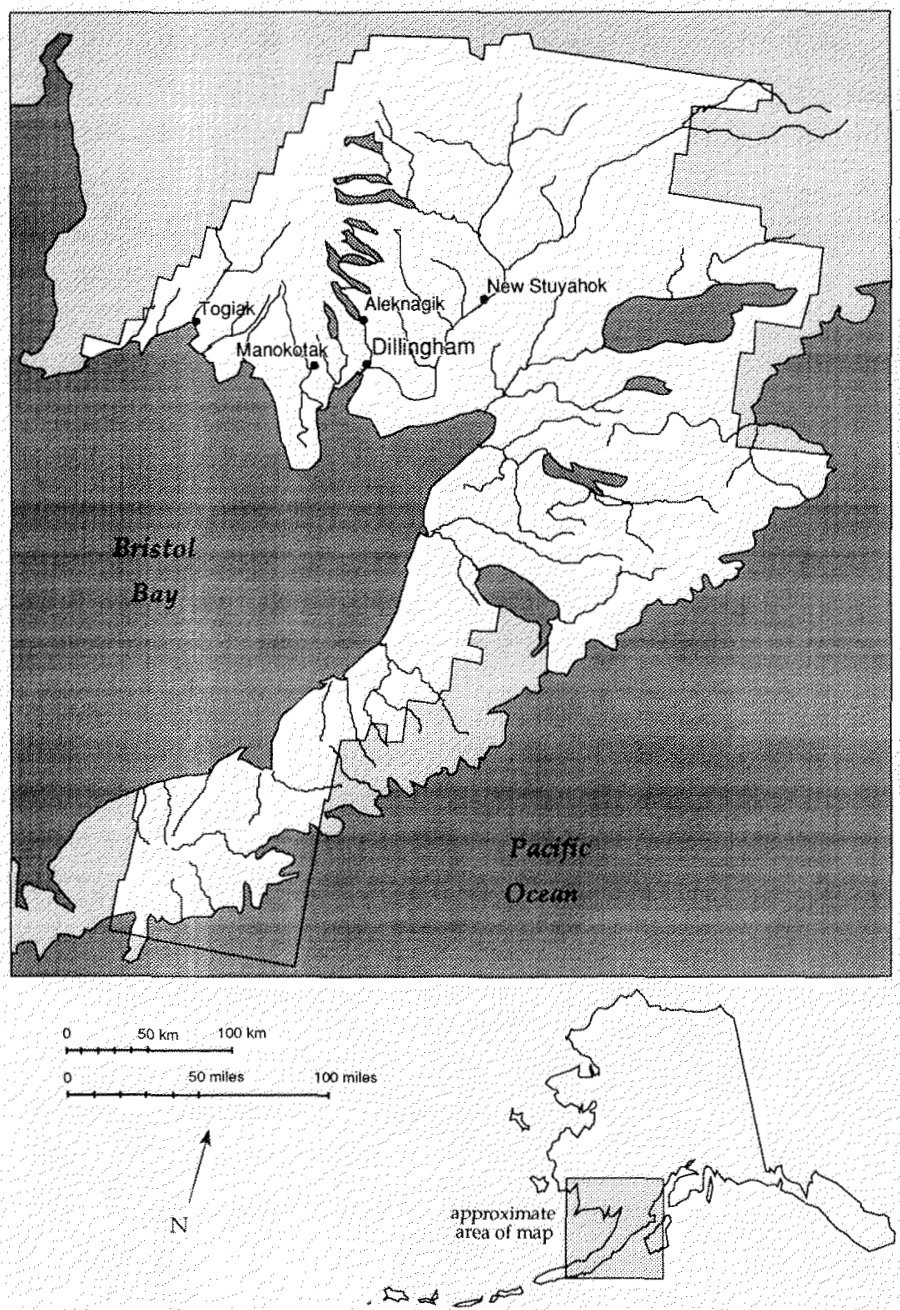

FIG. 2. Bristol Bay region communities studied, with regional corporation boundaries. contribution; in some villages country foods make up more than half of the diet. Population growth and increasing environmental pressures (including those brought by resource development) limit the potential of renewable-resource harvesting as a long-term food or cash source, however.

\section{ANCSA AND MOLLY HOOTCH}

Two legal events of the 1970 s reverberate in the communities we studied. The 1971 Alaska Native Claims Settlement Act (ANCSA) paved the way for Prudhoe Bay oil development by extinguishing all Native land claims in return for $\$ 962.5$ million and $178000 \mathrm{~km}^{2}$ of land, about one-ninth of Alaska. "A complex piece of legislation with even more complicated consequences" (Burch, 1979:10), the act created twelve Native-owned regional corporations and granted them mineral rights to all the settlement lands. Surface land rights and/or cash were divided among these twelve, a thirteenth regional corporation for nonresident Natives, 200-odd village corporations, and special-case corporations for Natives living in mainly non-Native areas. ANCSA gave the regional corporations broad responsibilities to administer the settlement, aid village corporations, invest money, and operate businesses for profit. They became dominant Native institutions (Burch, 1979).

The Northwest Alaska Native Association (NANA) Regional Corporation, with 4800 Native shareholders, received $\$ 60.2$ million and over $5600 \mathrm{~km}^{2}$ of land (Robinson et al., 1989). NANA's land selections included the Red Dog Creek area (named for a bush pilot's dog), which contains a valuable mineral deposit. In 1982 NANA signed an agreement with Cominco Alaska to develop the Red Dog Mine atop an ore body estimated at 77 million metric tons of $17.1 \%$ zinc, $5 \%$ lead, and $78 \mathrm{grams} /$ ton silver. Production began in 1990, and Cominco expects it to continue for 50 years. Under their agreement Cominco pays royalties to NANA and promised to seek $100 \%$ Native (NANA shareholder) employment by 2002 , the twelfth year of operation. According to the NANA 1991 Annual Report, the mine pays its Native workforce about $\$ 13$ million a year.

Red Dog royalties, low-risk stocks and bonds, joint ventures, and resource royalties shared from other regional corporations (as stipulated by ANCSA) provide most of NANA's income. To promote development and give shareholders jobs and training, NANA also made regional investments, including real estate, a hotel, a seafood company, and a jade processing facility. The regional investments all incurred losses in 1991 and 1992. Moneylosing business ventures have been common among ANCSA's regional corporations. Robinson et al. (1989:266), analyzing the poor financial condition of many regional corporations, point out that they are "located in areas with few low-risk investment opportunities, little socio-economic infrastructure, and small, isolated markets." Furthermore regional corporation ownership is diffuse, with shares that, unlike stocks of ordinary businesses, are not freely transferable. Regional corporations arose from legislation rather than entrepreneurial ideas and often lacked experienced managers. Such economic handicaps make ANCSA "legislation at war with itself . . . 
restrictions on the organizational form of ANCSA firms resulted in the dissipation of native wealth rather than its protection" (Karpoff and Rice, 1989:100). Because of Red Dog Mine, NANA is among the more profitable regional corporations.

A second legal landmark was the out-of-court settlement of a lawsuit (Hootch $v$. Lind) in 1976. Under this settlement, the state of Alaska agreed to support high school education in rural communities. Previously, rural students had to leave home for boarding school to continue their education. The boarding school experience was jarring for many Natives, as was re-entry into their home villages after years away. Some returning villagers could no longer speak the language they were raised in and felt alienated from village life.

The "Molly Hootch decision" reduced the necessity of boarding school by establishing new high school programs in over 95 rural communities (Chance, 1990). Such bush schooling is costly: the Northwest Arctic School District spent about \$12 924 per student over 1991-92. At Kotzebue High School, over $\$ 2000$ per student went for student activities alone. Much of this involves flying plane loads of students to basketball games and other events (no roads connect these communities). But young people can now attend high school without leaving their home communities. Native graduation rates have increased substantially (Alaska Federation of Natives, 1989).

The Molly Hootch decision alleviated some concerns, while raising others. Towns like Kotzebue and Dillingham each have more than 100 grade 9-12 students, enough to form high schools with some variety in teachers and facilities. Small villages, however, lack a critical mass of students. The villages we studied all had 40 students or less, and sometimes fewer than 12, in grades 9-12 combined. The number of teachers, classes, library books, social and athletic opportunities, and other parameters are necessarily compressed in small schools. Teachers covering multiple subjects have less chance to develop the specialized knowledge expected of high school teachers elsewhere. Most villages cannot support a certified industrial arts instructor, limiting their ability to teach shop or woodworking skills. In a few villages, the grades 9-12 program consists of a single teacher or classroom; elsewhere resources may be shared with adjacent $\mathrm{K}-8$ programs.

Whereas boarding schools worried some parents by requiring too much acculturation, rural high schools worry others by requiring too little. As Oswalt (1990:143) remarks about Kuskokwim River communities:

The problem of retaining the sense of Eskimoness while adequately preparing students to compete effectively with other Alaskans for jobs has not yet been solved. . . . The results of establishing village high schools as one means of providing a better learning environment suggest that this may only perpetuate the inferior quality of Kuskokwim secondary education.

Our study found many students concerned about their school's limitations. Such doubts affect self-confidence, aspirations, and ultimately what they do.

\section{DATA COLLECTION}

We collected data from high school students through surveys (spring 1992) and small-group interviews (1992-93).
Following guidelines and ethics set forth by the National Academy's Committee on Arctic Social Sciences (1989), we began by seeking input and involvement of Natives in the research areas. The Northwest Arctic School District School Board and school superintendents from the Dillingham City School District and the Southwest Region Schools offered suggestions for improvement before approving the study design. We mailed bundles of questionnaires to ten school principals in the Northwest Arctic and five in the Bristol Bay area. These principals took responsibility for administering questionnaires to students in grades 9-12 during March and April 1992. At that time the Northwest Arctic reported 381 students enrolled; we obtained 282 questionnaires, for a $74 \%$ response rate. We had a $67 \%$ response (148 out of 221 students) from the Bristol Bay region. Our data thus encompass large majorities of the high school students in both districts. Table 1 lists response rates for each community.

After analyzing these surveys, we carried results back to the cooperating schools and presented them to administrators, teachers, and students. Our goals on these visits were to understand and "reality check" the survey statistics, while at the same time giving something back to the people we were studying. For example, before describing survey results we invited students to speculate about what differences we had found between villages, and why. This part went as planned, but the students also showed an unexpectedly keen interest in using our notebook computers directly to explore the survey results themselves (Fig. 3). They wanted to compare their own community with its neighbors or boys with girls, regarding such variables as migration intentions, college aspirations, and subjective items, such as "You are out of luck here if you happen to be different" or "I feel very much that I belong here." Several classes devoted two full periods to this unplanned investigation, with no intervention from researchers or teachers beyond explaining the computer program's command syntax. In response to the surprising level of interest, we began organizing classroom visits around hands-on demonstrations of how to analyze (their) survey data. Even by suburban U.S. standards, bush schools are well equipped with computer hardware and have many students comfortable in its use.

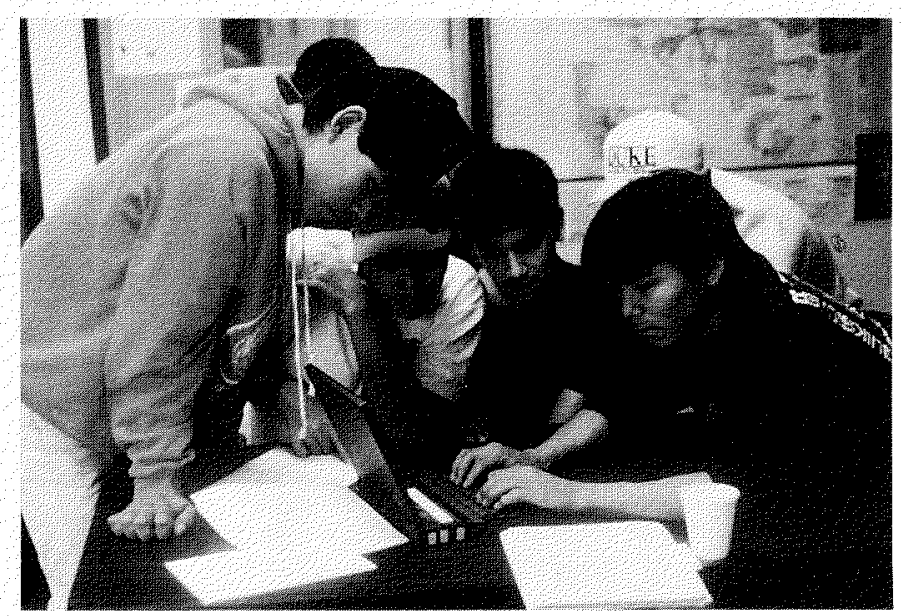

FIG. 3. Students in Kiana use the authors' notebook computer to compare their own survey responses with those from other villages. 
The high school surveys tell us what currently enrolled students expect to do after finishing high school. In order to compare their expectations with actual postgraduate experiences, we also collected data from people who graduated from these same schools between 1987 and 1991. We trained six local residents (Inupiat from the Northwest Arctic and Yup'ik from Bristol Bay) as interviewers to conduct this phase of the project. They interviewed 144 Bristol Bay and 68 Northwest Arctic graduates, obtaining $54 \%$ and $12 \%$ response rates - too low, especially in the Arctic, to claim representative samples, though on major points the graduates' data agreed with our student survey results.

The remainder of this paper describes findings from the high school surveys. For several reasons (including the presence of Red Dog Mine), we expected to see substantial differences between Northwest Arctic and Bristol Bay adolescents. Some regional differences did appear, but we also encountered sharp contrasts between village and town students. The pattern of these village-town contrasts was generally similar in both regions.

\section{EDUCATIONAL ASPIRATIONS}

Richard Condon (1987:157) observes that "schools have become the primary acculturative agents in most modern Inuit settlements." Their role transcends the classrooms. In many villages the school is the dominant building and the main employer (Fig. 4). Social life centers around evening basketball games in the gym. Students told us that the afternoon hours between school closing and its reopening for evening basketball were "dead time," with nothing much to do.

Elsewhere in the U.S., college-aspiring students commonly worry about getting accepted and affording tuition. We encountered few such worries among Native Alaskan high schoolers. Several stated that due to preference policies they can readily gain admission and "Anyone who works okay

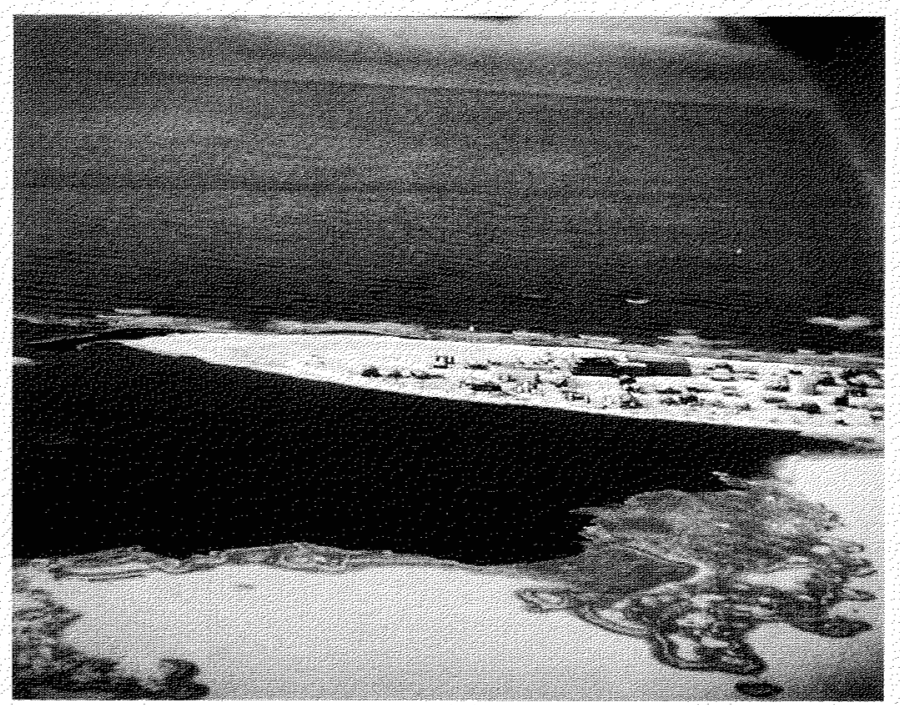

FIG. 4. Kivalina as seen trom the air. McQueen School (center) dominates this view of the village, which is on a gravel spit that loses one metre per year to erosion by the Chukchi Sea. can get a scholarship to college." Instead, they worry about whether bush education is adequately preparing them to survive in college once they get there. Specific shortcomings mentioned include too-easy texts and course work, limited course offerings, and teachers covering subjects outside their training. Town students complained loudest, although such problems objectively are worse in the villages. In towns and villages, students' concerns reflect their experience of watching older siblings or friends leave hopefully for college, only to return without graduating. The Alaska Federation of Natives (1989:58) points out another sign of trouble in bush education:

The increasing number of high school diplomas being awarded to Native graduates of small village high schools masks many graduates' abysmally low standardized achievement test scores.

Teachers we talked with could remember few instances of a village high school graduate successfully completing college. Local-born college graduates tend to have received secondary educations elsewhere, often at boarding school.

Town and village students agree that town schools expect more from their students, but some say that even the town schools do not challenge them enough. For example, some town students were upset to discover that they were reading below-grade-level textbooks. This was attributed to districtwide text purchasing: people setting the standards chose undemanding books they thought would work in the village schools. An unwelcome sense of superiority over less acculturated upriver villagers surfaced during preparations for a basketball game, when town students put up posters saying "Kill the River Rats!"

Figure 5 graphs Bristol Bay and Northwest Arctic schools on two basic dimensions: number of high school students enrolled and percentage of our respondents who say they plan to attend a university. Both regions exhibit similar patterns. The town schools (Dillingham and Kotzebue) stand apart from village schools because they are larger and have high proportions of university-aspiring students. Among village schools we see wide variation in the percentage with university

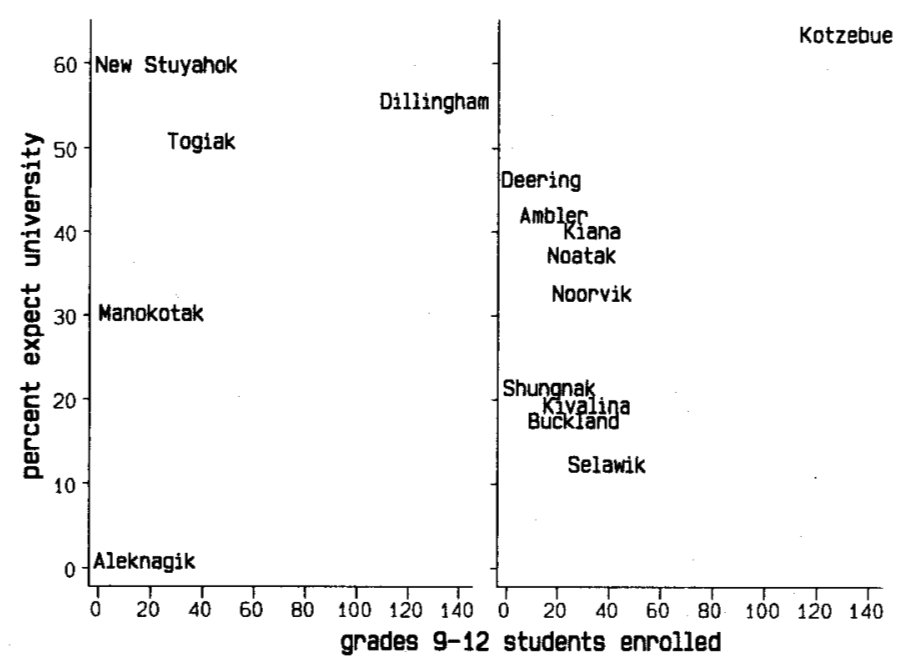

FIG. 5. Percentage of students expecting to attend a university versus high school size for five Bristol Bay schools (left) and ten Northwest Arctic schools (right). 
aspirations. This variation reflects both real differences between schools and the instability of percentages calculated from small base numbers (only four students at Aleknagik, for example, or ten at New Stuyahok). Experience suggests that the percentage of these students actually leaving for college or completing a first year will fall short of the hopes graphed in Figure 5.

Apart from teaching, the villages offer few jobs for people with college educations. Consequently, going to college often implies the intention to migrate away. Indeed, jobs in many villages are so scarce that almost anyone who wants fulltime employment must consider outmigration. A major exception to this rule in the Northwest Arctic is employment at the Red Dog Mine.

\section{JOBS IN MINING OR OIL}

Schemes for northern economic development mostly focus on nonrenewable-resource extraction. Neither Bristol Bay nor the Northwest Arctic has oil wells, but the Red Dog Mine looms large in many Northwest Arctic students' plans (Seyfrit and Hamilton, 1992b). Both NANA and Red Dog's operator, Cominco Alaska, recognize that progress toward their $100 \%$ Native employment goal depends upon the aspirations and readiness of local youth.

About 30\% of Northwest Arctic students expect to work in the mining or oil industries - primarily at Red Dog Mine. In contrast, less than $5 \%$ of Bristol Bay students expect such work. Figure 6 breaks these percentages down by region, village/town, gender, and place of birth. For example, $46 \%$ of the male Northwest Arctic village students and 35\% of the male Kotzebue students expect to work in mining or oil at some point in their lives. Slightly higher percentages (48\% and $37 \%$, also graphed in Fig. 6) result when we restrict the analysis to only those students born in the region. Horizontal lines in Figure 6 show the overall percentage (21\%) expecting mining or oil employment.
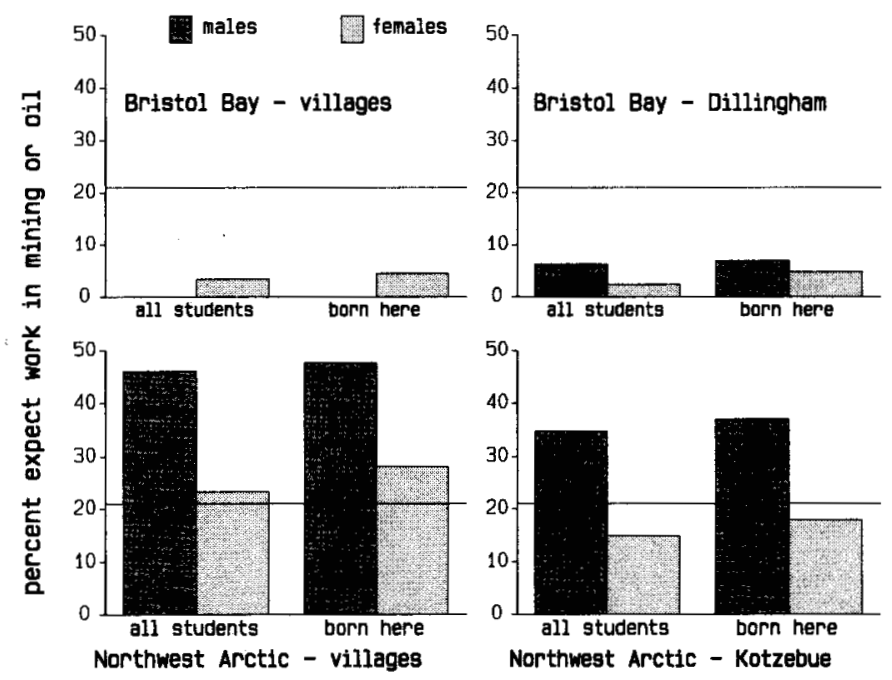

FIG. 6. Percentage of students who expect to work in mining or oil by village/town and region (all students and students born in the region are shown separately).
Figure 6 permits several quick comparisons. Due mainly to Red Dog, Northwest Arctic students are much more inclined than their Bristol Bay counterparts to expect work in nonrenewable-resource industries. Among Northwest Arctic students, males about twice as often as females expect mining or oil employment. Northwest Arctic village students are significantly more likely than Kotzebue students to expect mining/oil jobs. Finally, the fraction expecting mining/oil work is slightly higher among locally born Northwest Arctic students than it is among Northwest Arctic students in general. Too few Bristol Bay students expect mining/oil jobs to permit meaningful comparisons within that region.

Other analyses confirm that Red Dog aspirations occur most often among locally born Northwest Arctic village males. These young men also tend not to have academic ambitions or to plan migration out of their home region. Red Dog appeals less to more acculturated students, who seek other avenues for upward/outward mobility. It provides a unique opportunity, however, for young men who want to remain in their village and participate in traditional subsistence activities.

Efforts by NANA and Cominco to accommodate this labor pool include extensive training and support, as well as work rotation schedules (typically four weeks on, two weeks off) designed not to interfere with subsistence. So far good intentions have not been enough, however, as progress on Native employment is stalled by high turnover. In October 1992, for example, NANA reported that about two-thirds of the recently hired shareholders quit Red Dog within their first six months. The operators are presently experimenting with ways to improve retention.

\section{OUTMIGRATION}

On visits following our survey, we asked groups of students what it was like being a teenager in their town or village. The first response was almost always an emphatic "Boring!" (We heard the same one-word answer from village students in Scotland and Newfoundland, too.) The following, fairly typical, outbursts came from students in a coastal Alaskan village in response to "What is it like being a teenager here?" "Boring. The only thing exciting in town is school." "There's nothing for us here." "Nothing to do." "No jobs." "Just lonely streets."

Besides the lack of jobs, specific complaints usually included no malls, no roads, and no teen-oriented activities. Other students defended their community, citing the "easy life," freedom, snow machines, and opportunities to go hunting. Who could want to live anywhere else?

High birth rates in Native villages and towns outpace the growth of job opportunities. Apart from the Northwest Arctic's Red Dog Mine, most jobs require relocating to cities or at least regional hubs. Outmigration opens wider opportunities for those who leave. At the same time, outmigration impoverishes the communities left behind, as it draws off energetic young people.

Figure 7 , organized similarly to Figure 6 , graphs the percentage of surveyed students who expect to live most of the rest of their lives away from their present region. Its most 

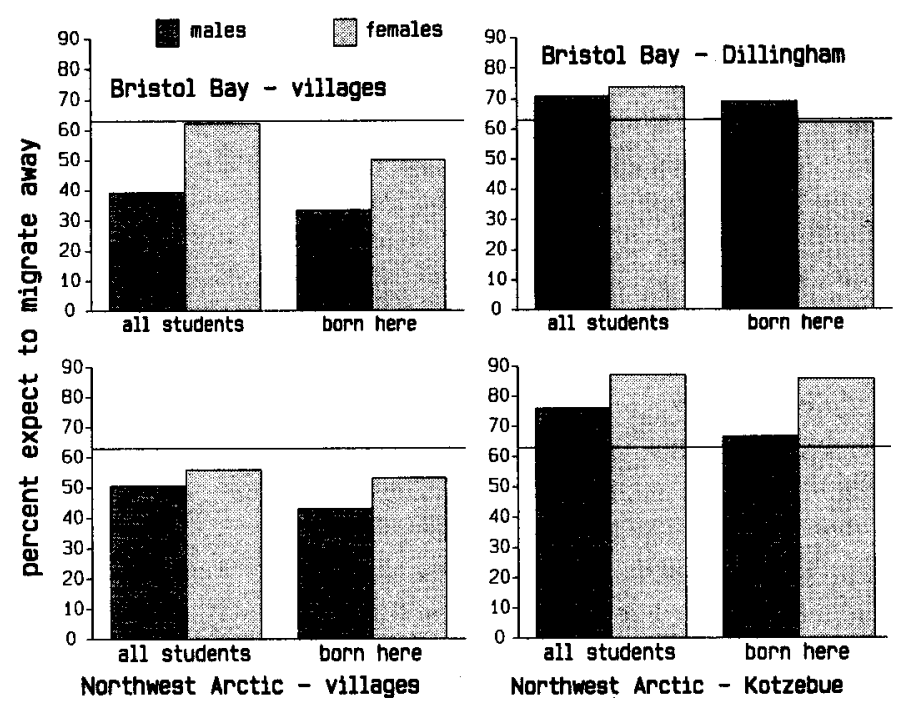

FIG. 7. Percentage of students who expect to live most of their lives out of the region by village/town and region (all students and students born in the region are shown separately).

striking message is how many of these students ( $63 \%$ overall, shown by horizontal lines) say they will leave. This may be unrealistic - permanent migration, like completing college, often proves problematic - but it does reflect students' images of their lives. Such images influence the choices they make and later on their sense of failure or success.

Migration expectations vary with village/town location, gender, and place of birth. Town students are much more likely than village students to expect outmigration. In seven of the eight comparisons of Figure 7, young women appear more inclined toward outmigration than young men. Gender differences are greatest among Bristol Bay village and Kotzebue students. Locally born students are slightly less outward looking. These observations apply equally to Bristol Bay and Northwest Arctic students; we see no significant differences between regions.

The percentage of locally born students expecting to leave the region tends to rise with community size, as shown in Figure 8. Robust regression finds a statistically significant upward curve $\left(R^{2}=.42, P<.05\right.$, method detailed in Hamilton, 1992, 1993). Similar curves result if we analyze Bristol Bay and Northwest Arctic data separately. Symbol areas in Figure 8 are proportional to high school enrollment, with the shaded portion indicating survey respondents.

Town students expecting to leave the region include many who also say they will leave Alaska (35\%, compared with just $8 \%$ of village students). Figures 7 and 8 do not reflect this contrast, nor do they show local outmigration - villagers intending moves to larger towns within the same region.

As a footnote on migration, Native Alaskan villages attract small numbers of white people who come solely for lifestyle reasons (in contrast to white teachers, pilots, commercial fishermen, etc., whose motives include employment). Lifestyle migrants are sometimes viewed skeptically; educators characterized them as "white renegades" or "leftover hippies." Another village resident told us: "One white family did move in, but nobody can figure out why.

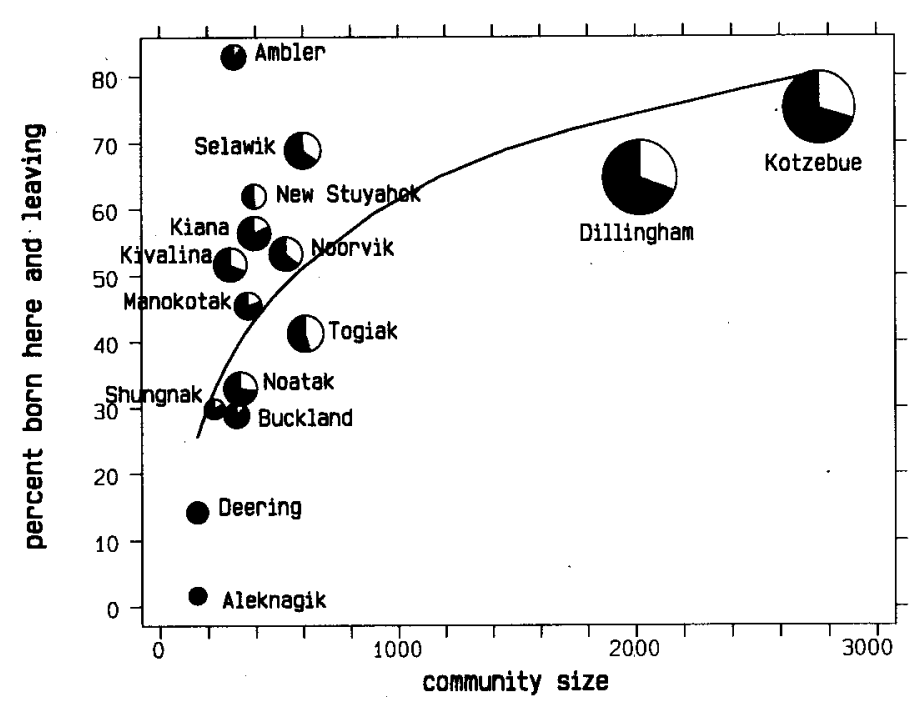

FIG. 8. Percentage of local-born students expecting to migrate versus community size, with regression curve $\left(R^{2}=.42, P<.05\right)$. Symbol size reflects total high school enrollment, and shaded area shows the proportion of survey respondents.

We keep watching 'America's Most Wanted' to see if they show up." Implicit in these comments is the opinion that normal outsiders would not envy village life.

\section{MIGRATION AND GENDER}

The gender disparity in migration expectations seen in Figure 7 deserves closer examination. Young women more often want to leave and more often succeed in doing so. Kizzia (1991:61-62) quotes a Seward Peninsula man:

$\mathrm{He}$ told me one of the biggest problems in the villages was that the best Native girls wanted nothing to do with traditional bush life. Too much work for the women. They found some way to move to the cities, leaving the guys behind.

Bush life is hard for young women because of expectations that they should help with child care and domestic work, contributing any earnings to their families. Soon they will have babies of their own. Meanwhile young men have more time for hunting or hanging out; their earnings might go towards a snow machine or rifle (Condon, 1987).

When they venture away from the bush, however, women tend to have better success than men in holding a job or completing school (Kleinfeld et al., 1983, 1986). Kleinfeld (1992:20-21) documents the gender gap at University of Alaska, obșerving that "the change has occurred recently, and the gap is steadily widening." Boys in one village told us they wanted to follow in their fathers' footsteps as fishermen. We asked the girls, did they want to follow in their mothers' footsteps? Their response was immediate laughter. "We want careers," one girl explained. They saw no careers for women in the village.

Many villages now contain fewer young women than men, whereas magnet cities have more young Native women than men. For the Northwest Arctic borough as a whole, in the 15-39 age group there are 113 Native men for every 100 Native women, reflecting net female outmigration. Anchorage, the state's metropolitan center (and a principal 
migration destination) has only 83 Native men per 100 women in this mobile, marriageable age group. In Fairbanks the ratio is $89 / 100$ and in Juneau 91/100.

Within the Northwest Arctic, village 15-39 Native male/female sex ratios range from even (Kiana) to $148 / 100$ (Shungnak), with a median of $132 / 100$. The excess of young men in villages puts pressure on younger girls who have not left - but may soon find reason to. A resident described the situation in one community:

Girls who stay in the village get pregnant. Most of the young ladies have left to find work. They got jobs at Red Dog, the Slope, Anchorage. Young men leave, but they come back. Most are unemployed -24 hours of daylight and nothing to do. They focus on high school girls who are almost their victims.

Unmarried men have less reason than married men to hold a steady job and more freedom to spend whatever money they earn on vices and personal luxuries, so an excess of young men in villages could fuel other social problems as well (see Kleinfeld et al., 1983, and sources they cite). Young Native males experience particularly high rates of suicide, homicide, and accidental death (McNabb, 1990).

Figure 9 shows the demographic contrast between villages and towns. Enough village women move into Kotzebue to more than offset any outflow of Kotzebue women: the town has only 91 Native men per 100 Native women in the 15-39 age group. Likewise Dillingham, the Bristol Bay region hub, has just 85 young Native men per 100 Native women. Bristol Bay villages, like their Northwest Arctic counterparts, tend to have at least slightly more young men than women. The expectations shown at top left in Figure 7 suggest that Bristol Bay village imbalances might soon increase further. Robust regression detects a curvilinear relation between sex ratio and population $\left(R^{2}=.33, P<.05\right)$.

\section{DISCUSSION}

Adolescents living in "way-station" towns exhibit greater acculturation than their village peers in several interrelated

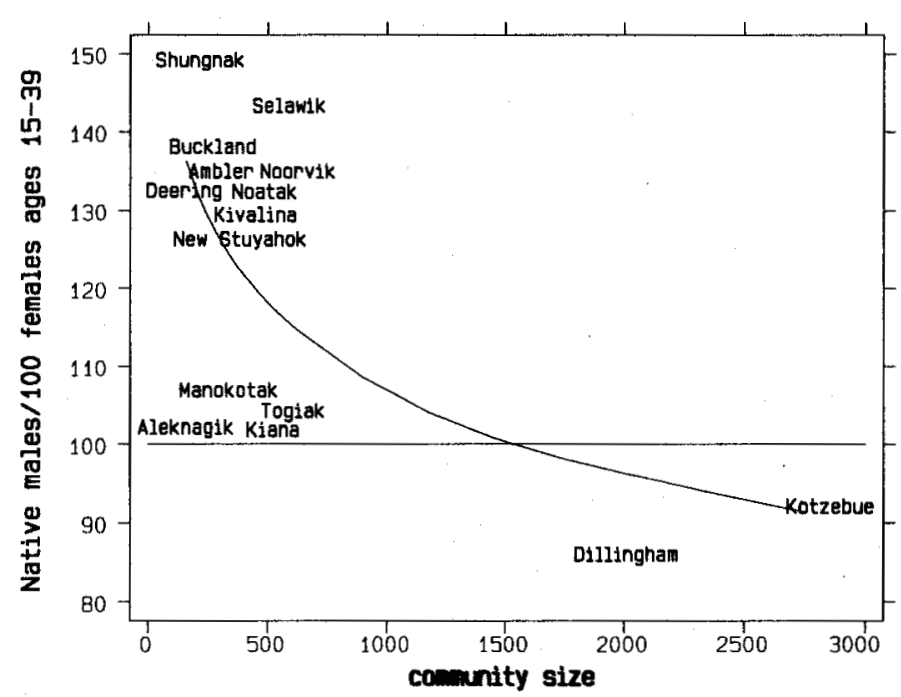

FIG. 9. Male/female ratio among Natives ages 15-39 versus community size, with regression curve $\left(R^{2}=.33, P<.05\right)$. respects. They express more confidence - though also more criticism - regarding their high school educations as preparation for college, and they more often plan to go on to college themselves. Furthermore they tend to feel weaker social ties to their present communities than do village students. Academic self-confidence, weaker social ties, and outwardlooking educational/professional aspirations contribute to town students' greater likelihood of permanent outmigration. Even in the villages, however, about half the students expect outmigration. (For a more formal statistical analysis of Alaskan students' migration intentions see Hamilton and Seyfrit, 1993. Parallel work based upon Scottish data appears in Seyfrit and Hamilton, 1992a.)

In the Northwest Arctic, young village males - the youth segment least prepared to leave - most often express interest in working at Red Dog. Its location in the region, commitment to Native hiring and training, free transportation to the site, and work schedules tailored to accommodate subsistence activities all make the mine seem uniquely attractive for young men who do not want to migrate, go to college, or give up subsistence hunting.

Young and McDermott's (1988) analysis of employment training programs in Canada's Northwest Territories concludes that most expect rapid acculturation. Red Dog training, however, appears to fit Young and McDermott's description of a program "delivered in a manner that better accommodates northern indigenous cultures." Problems arise nonetheless because the mine still requires more acculturation (e.g., catch planes on time, keep job for years, earn promotions) than many Natives want. Even among young people most interested in Red Dog, few see it as a career. Instead they tend to view it as a temporary way to earn money. The high turnover among employees conforms to this view, as it hampers NANA/Cominco efforts to bring Natives up through the ranks into management and upgrade skill levels in the Northwest Arctic labor pool.

Similar problems beset other arctic development projects. The hardships of mine work and its conflicts with traditional values and subsistence activities contributed to turnover and absenteeism problems at the Qullissat coal mine in Greenland, operated 1924-72 (Haagen, 1982), the North Rankin Nickel Mine on Hudson Bay, 1953-62 (Duffy, 1988), and the Nanisivik lead/zinc mine operating on Baffin Island since 1976 (Hobart, 1982). The Nanisivik mine initially aimed for a $60 \%$ Native workforce, but many Inuit worked there no more than one or two months. By 1992 the mine had long since abandoned its $60 \%$ goal, settling instead for $25 \%$, which is still "one of the best native-hiring records in the Canadian North" (Los Angeles Times, 10/6/92). Greenland Inuit at Marmorilik likewise viewed their lead/zinc mine jobs as temporary (Dahl and Lyberth, cited in Haagen, 1982). Canadian and Alaskan Inuit employment patterns in recent energy projects continue to indicate preferences for temporary or part-time jobs, especially among men (Kleinfeld et al., 1983).

In many of these instances, high turnover continued despite employer promises to improve Native hiring and retention. NANA, aware of this history and of its own disappointments, 
is currently reorganizing the Red Dog training program in hopes of doing better. Efforts to instill an industrial work ethic must somehow also accommodate both traditional values and the hybrid culture of modern bush communities.

Young women less often look toward mine work for their future, and more often look out of their village or town. Regional and urban centers offer them wider choices. A growing excess of young men remaining in villages exacerbates social problems and adds to the push for female outmigration. Census data confirm that many villages now have more young men than women, whereas the regional and urban centers have correspondingly more young Native women than men.

This pattern extends beyond the communities we studied. Robert-Lamblin (1982:112) reports a shortage of women in Aleut villages, despite more female births and lower female mortality:

The natural surplus of females is more than balanced by the phenomenon . . . of the emigration of female adults to more urban centers. Since the last few years, women have departed in search of a Mainland husband, preferably a White.

Similarly, Langgaard (1986:310) sees an "alarming" shortage of women in some Greenland Inuit villages. Through migration, education, employment, and intermarriage, it appears that many northern women are following their own acculturation path, independent and deeper than that of men.

To further delineate the consequences of migration flow and other demographic shifts, we have begun work on a population database covering all communities in Alaska. This database will provide background for more detailed longitudinal studies of individual and community change.

\section{REFERENCES}

ALASKA FEDERATION OF NATIVES. 1989. The AFN report on the status of Alaska Natives: A call for action. Anchorage: Alaska Federation of Natives.

BURCH, E.S., Jr. 1979. Native claims in Alaska: An overview. Etudes/Inuit/Studies 3(1):7-30.

CHANCE, N.A. 1990. The Inupiat and arctic Alaska: An ethnography of development. Fort Worth: Holt, Rinehart and Winston.

COMMITTEE ON ARCTIC SOCIAL SCIENCES. 1989. Arctic social science: An agenda for action. Washington, D.C.: National Academy Press.

CONDON, R.G. 1987. Inuit youth: Growth and change in the Canadian Arctic. New Brunswick: Rutgers University Press.
DUFFY, R.Q. 1988. The road to Nunavut: The progress of the Eastern Arctic Inuit since the Second World War. Montreal: McGill-Queen's University Press.

FALL, J.A. 1990. The division of subsistence of the Alaska Department of Fish and Game: An overview of its research program and findings: 1980-1990. Arctic Anthropology 27(2):68-92.

FIENUP-RIORDAN, A. 1990. Eskimo essays: Yup'ik lives and how we see them. New Brunswick: Rutgers University Press.

GRABURN, N.H.H. 1982. Television and the Canadian Inuit. Etudes/Inuit/Studies 6(1):7-17.

HAAGEN, B. 1982. The coal mine at Qullissat in Greenland. Etudes/Inuit/Studies 6(1):75-97.

HAMILTON, L.C. 1992. Regression with graphics: A second course in applied statistics. Pacific Grove, CA: Brooks/Cole. 1993. Statistics with Stata 3. Belmont, CA: Duxbury.

HAMILTON, L.C., and SEYFRIT, C.L. 1993. Interpreting multinomial logistic regression. Stata Technical Bulletin 13:24-28.

HOBART, C.W. 1982. Inuit employment at the Nanisivik mine on Baffin Island. Etudes/Inuit/Studies 6(1):53-74.

JORGENSEN, J.G. 1990. Oil age Eskimos. Berkeley: University of California Press.

KARPOFF, J.M., and RICE, E.M. 1989. Organizational form, share transferability, and firm performance. Journal of Financial Economics 24:69-105.

KIZZIA, T. 1991. The wake of the unseen object: Among the Native cultures of bush Alaska. New York: Henry Holt.

KLEINFELD, J. 1992. Alaska Native education: Issues in the nineties. Anchorage: Henry M. Jackson Foundation.

KLEINFELD, J., GORSUCH, L., and KERR, J. 1986. Minorities in higher education: The changing North. Fairbanks: Institute of Social and Economic Research.

KLEINFELD, J., KRUSE, J., and TRAVIS, R. 1983. Inupiat participation in the wage economy: Effects of culturally adapted jobs. Arctic Anthropology 20(1):1-21

LANGGAARD, P. 1986. Modernization and traditional interpersonal relations in a small Greenlandic community: A case study from southern Greenland. Arctic Anthropology 23(1-2):299-314.

McNABB, S. 1990. Native health status and native health policy: Current dilemmas at the federal level. Arctic Anthropology 27(1):20-35.

OSWALT, W.H. 1990. Bashful no longer: An Alaskan Eskimo ethnohistory, 1778-1988. Norman: University of Oklahoma Press.

ROBERT-LAMBLIN, J. 1982. An historical and contemporary demography of Akutan, an Aleutian village. Etudes/Inuit/Studies 6(1):99-126.

ROBINSON, M., PRETES, M., and WUTTUNEE, W. 1989. Investment strategies for northern cash windfalls: Learning from the Alaskan experience. Arctic 42(3):265-276.

SEYFRIT, C.L., and HAMILTON, L.C. 1992a. Who will leave? Oil, migration, and Scottish island youth. Society and Natural Resources 5(3):263-276

SEYFRIT, C.L., and HAMILTON, L.C. 1992b. Social impacts of resource development on arctic adolescents. Arctic Research of the United States 6(Fall):57-61.

YOUNG, R.A., and McDERMOTT, P. 1988. Employment training programs and acculturation of native peoples in Canada's Northwest Territories. Arctic 41(3):195-202.

WOLFE, R.J., and WALKER, R.J. 1987. Subsistence economies in Alaska: Productivity, geography, and development impacts. Arctic Anthropology 24(2):56-81. 